\title{
Coagulating Gland
}

National Cancer Institute

\section{Source}

National Cancer Institute. Coagulating Gland. NCI Thesaurus. Code C77618.

The anterior lobe of the prostate gland in animals. 